\section{Antistreptolysin 0 titer in health and disease: levels and significance}

\author{
Alyaa Amal Kotby, \\ Nevin Mamdouh Habeeb, \\ Sahar Ezz El Elarab \\ Pediatric Department, Ain Shams \\ University, Early Cancer Detection Unit \\ Ain Shams University Hospital, Cairo, \\ Egypt
}

\section{Abstract}

Over diagnosis of acute rheumatic fever (ARF) based on a raised antistreptolysin 0 titer (ASOT) is not uncommon in endemic areas. In this study, 660 children (aged $9.2 \pm 1.7$ years) were recruited consecutively and classified as: G1 (control group, $\mathrm{n}=200$ healthy children), $\mathrm{G} 2$ ( $\mathrm{n}=20$ with ARF $1^{\text {st }}$ attack), G3 ( $\mathrm{n}=40$ with recurrent ARF), G4 (n=100 with rheumatic heart disease (RHD) on long acting penicillin (LAP)), G5 ( $\mathrm{n}=100$ with acute follicular tonsillitis), and G6 ( $\mathrm{n}=200$ healthy children with history of repeated follicular tonsillitis more than three times a year). Serum ASOT was measured by latex agglutination. Upper limit of normal (ULN) ASOT (80th percentile) was $400 \mathrm{IU}$ in G1, $200 \mathrm{IU}$ in G4, and $1600 \mathrm{IU}$ in G6. Significantly high levels were seen in ARF 1st attack when compared to groups 1 and $5(\mathrm{P}<0.001$ and $\mathrm{P}<0.05$, respectively). ASOT was significantly high in children over ten years of age, during winter and in those with acute rheumatic carditis. ASOT showed significant direct correlation with the number of attacks of tonsillitis $(\mathrm{P}<0.05)$. Egyptian children have high ULN ASOT reaching $400 \mathrm{IU}$. This has to be taken into consideration when interpreting its values in suspected ARF. A rise in ASOT is less prominent in recurrent ARF compared to 1st attack, and acute and recurrent tonsillitis. Basal levels of ASOT increase with age but the pattern of increase during infection is not age dependent.

\section{Introduction}

Although acute rheumatic fever (ARF) is relatively rare in developed economies, it is much more common in the developing world and among aboriginal populations. ${ }^{1}$ It has been estimated that worldwide 15.6 million people have RHD. ${ }^{2}$ Regions of major public health concern include the Middle East, the Indian subcontinent, and some areas of Africa and South America. ${ }^{3}$ The prevalence of RHD was reported to be 5.1 per 1000 in school children in Egypt. ${ }^{4}$ In addition, the course of ARF was found to be severe and aggressive in different parts of the country where rheumatic fever is still one of Egypt's major public health problems. 5,6

Evidence of a host immune response to group A $\beta$ hemolytic streptococcal throat infection (GA $\beta H S$ ) is required to confirm the diagnosis of rheumatic fever.7,8 Although ASOT has been used to diagnose recent infection, interpretative criteria suggested by manufacturers of commercial antibody test kits are not suitable for children. It is not uncommon for laboratory personnel and physicians to misinterpret streptococcal antibody titers because of a failure to appreciate that the normal levels of these antibodies are higher among school-age children than among adults. ${ }^{9}$ Moreover, it is often not feasible to obtain acute and convalescent sera. Thus, the absolute value of ASO is of diagnostic importance. 10

Upper limit of normal (ULN) values of ASOT are known to vary also with respect to different geographical locations, season, and site of infection. $(11,12)$ Since over diagnosis of ARF based on a raised ASOT is not uncommon, the ULN value of ASO in normal children is of importance to interpret ASO titers in patients suspected to have ARF.

This study aimed to determine ASOT in normal children and in those with rheumatic fever and tonsillitis. The variation of ASOT with age and season was also studied.

\section{Materials and Methods}

This is a cross-sectional case control study conducted on 660 patients chosen consecutively from the Children's Hospital and Pediatric Cardiology clinic, Ain Shams University Hospital, a tertiary referral center in Cairo.

Subjects were classified into six groups.

Group 1: 200 apparently healthy children with no history of recent tonsillitis or sore throat served as a control group;

Group 2 (ARF): 20 cases in the 1st attack of ARF, diagnosed according to updated modified Jones criteria; 8

Group 3 (recurrent RF): 40 patients with recurrent ARF, diagnosed according to updated modified Jones criteria for recurrent rheumatic fever.8,13 They were non compliant to the LAP prophylaxis;

Group 4 (chronic RHD): 100 patients with chronic RHD, all of whom had mitral regurge with or without aortic regurge. They recieved LAP every two weeks based on the 1992 recommendations of Kassem et al. ${ }^{5}$ These patients had no history of acute follicular tonsillitis or rheumatic activity within three months prior to enrollment in the study.

Group 5 (acute follicular tonsillitis): 100
Correspondence: Nevin Mamdouh Habeeb, Department of Pediatrics, Faculty of Medicine, Ain Shams University, 15A Saraya Al Kobba square, Cairo, Egypt. Tel: +20.110 .830 .844 .

E-mail: nhabeeb69@yahoo.com

Key words: antistreptolysin 0 titer, rheumatic fever.

Received for publication: 18 September 2011. Revision received: 23 November 2011.

Accepted for publication: 25 November 2011.

This work is licensed under a Creative Commons Attribution NonCommercial 3.0 License (CC BYNC 3.0).

(C) Copyright A.A. Kotby et al., 2012

Licensee PAGEPress srl, Italy

Pediatric Reports 2012; 4:e8

doi:10.4081/pr.2012.e8

patients with acute follicular tonsillitis. Their inclusion criteria were: fever over $38^{\circ} \mathrm{C}$, tender anterior cervical lymphadenopathy, lack of cough and the presence of pharyngotonsillar exudates. 14

Group 6 (history of recurrent follicular tonsillitis): 200 apparently healthy normal children with past history of repeated follicular tonsillitis more than three times a year. Children with proven attack of acute follicular tonsillitis within the three months before enrollment in the study were excluded.

Each group was sub-classified into three subgroups according to age: $\leq 5,6-10$ and $\geq 10$ years. They were also classified according to the season of enrollment into the study: winter, spring, summer, and autumn. A full history was taken of all study subjects and they all underwent clinical examination with a particular emphasis on the presence of acute tonsillar inflammation, the number of attacks of acute follicular tonsillitis per year, criteria of rheumatic activity and RHD.

Blood specimens were collected by venipuncture from all subjects and used for ASOT measurement by rapid latex agglutination intended for semi quantitative determination of ASOT in serum using Avitex ASO test kit. Avitex ASO latex particles are coated with purified and stabilized streptolysin- 0 . When the latex suspension is mixed with serum containing elevated levels of ASO antibodies on a slide, clear agglutination is seen within $2 \mathrm{~min}$. This test has been calibrated to WHO ASO First International Standard Preparation 97/662. Isotonic saline serial dilutions of patients' sera were prepared $(1 / 2,1 / 4,1 / 8,1 / 16,1 / 32$, etc.). The serum ASO concentration could then be calculated approximately by multiplying the dilution factor (i.e. 2, 4, 8 or 16) by the detection limit. Kit controls were tested with each 
test run. Sera having titers between $200 \mathrm{lU} / \mathrm{mL}$ and $3500 \mathrm{lU} / \mathrm{mL}$ were reactive. This method was chosen because it is the widely used technique for ASOT measurement in Egypt.

The study was explained to the parents of the patients, written consent was given before enrollment, and the study was approved by the institutional ethical committee.

\section{Statistical analysis}

Upper limit of normal ASOT was calculated in groups without recent streptococcal infection (G1, 4 and 6 ) as the value exceeded by $20 \%$ of the studied population (80th percentile). ${ }^{12}$ ASOT values were positively skewed and so the raw data were log-transformed prior to using the statistical test, and the results were presented as geometric means and 95\% confidence intervals. ANOVA (analysis of variance) was used to test the difference about mean values of ASOT among the six groups, in different seasons and in different presentations of patients with acute rheumatic fever. Multiple comparisons between pairs of groups were performed using Bonferroni test (post hoc range test); results were presented as geometric mean (GMT) and 95\% confidence intervals (CI). To investigate the relationship between age and ASOT, Pearson's correlation coefficient was calculated. Data were analyzed using SPSS (version 15).

\section{Results}

Six hundred and sixty patients were included in this study. The groups are shown in Table 1. The mean age and male to female percentage of the different groups were recorded.

Group 1: $9.55 \pm 2.75$ years (42.5-57.5\%);

Group 2: $9.35 \pm 2.06$ years (60-40\%);

Group 3: $9.85 \pm 1.72$ (47.5-52.5\%);

Group 4: $9.81 \pm 2.7$ years (44-56\%);

Group 5: $8.42 \pm 2.8$ years (44-56\%);

Group 6: 8.64 2.8 years (46\%-54\%).

The data of ASOT in different groups are presented in Figure 1 and Table 1.

ASOT values were compared between each two studied groups as shown in Table 2.

Data of ASOT in age-based subgroups are shown in Table 3.

There was a statistically significant difference of ASOT between age subgroups in G1 $(\mathrm{P}<0.0001), \mathrm{G} 4(\mathrm{P}<0.001)$, and $\mathrm{G} 6(\mathrm{P}<0.0001)$; ASOT values were the highest at over ten years of age in all subgroups. In addition, there was a positive correlation between age and ASOT among subjects of $\mathrm{Gl}(\mathrm{r}=0.67, \mathrm{P}<0.0001)$, $\mathrm{G} 4(\mathrm{r}=0.422, \mathrm{P}<0.0001)$ and $\mathrm{G} 6 \quad(\mathrm{r}=0.606$, $\mathrm{P}<0.0001)$.

The ULN ASOT of groups 1, 4 and 6 in different seasons is presented in Figure 2. ASOT levels were significantly higher in winter and autumn in all groups $(\mathrm{P}<0.0001)$ except in group 6 in which levels in different seasons were comparable.

ASOT reached the highest value in patients with rheumatic carditis (GMT 1638 IU/mL, 95\% CI; 1534, 1749) with a statistically significant difference when compared with titers of patients with rheumatic chorea $(979.80 \mathrm{IU} / \mathrm{mL}$, 95\% CI; 675.09, 1422.03, $\mathrm{P}<0.0001)$ and with rheumatic arthritis (1361.18 IU/mL, 95\% CI; 1207.13, 1534.88, $\mathrm{P}<0.05)$.

Within group 6, ASOT showed significant direct correlation with the number of attacks of tonsillitis $(\mathrm{r}=0.61, \mathrm{P}<0.001)$ (Table 4).

\section{Discussion}

Many Authors have studied the ULN ASOT in different populations. It was 333 Todd's units in Minnesota, USA, $15240 \mathrm{IU} / \mathrm{mL}$ in another study conducted in different American states, ${ }^{9} 326 \mathrm{IU} / \mathrm{mL}$ in Korea, ${ }^{16} 305 \mathrm{IU} / \mathrm{mL}$ in Mombai, ${ }^{17} 239 \mathrm{IU} / \mathrm{mL}$ in a different region of India, $10200 \mathrm{IU} / \mathrm{mL}$ in Tanzania, 18 and 200 Todd's units in Sweden. ${ }^{19}$

Most of these values exceeded the normal level set by laboratories which is $200 \mathrm{IU} / \mathrm{mL}$. The ULN in our studied control group was even

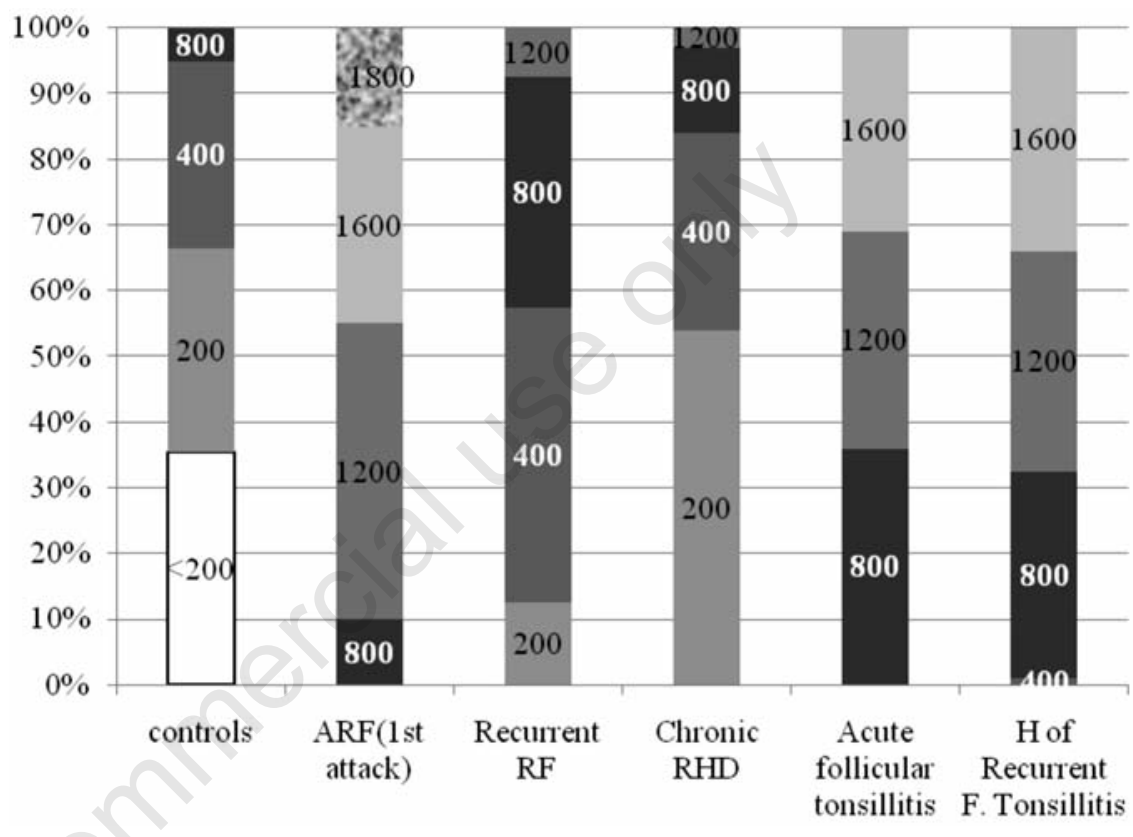

Figure 1. Antistreptolysin $\mathrm{O}$ titer in all groups. ARF, acute rheumatic fever; RHD, rheumatic heart disease; $\mathrm{H}$ of recurrent $\mathrm{F}$ tonsillitis, history of recurrent follicular tonsillitis.

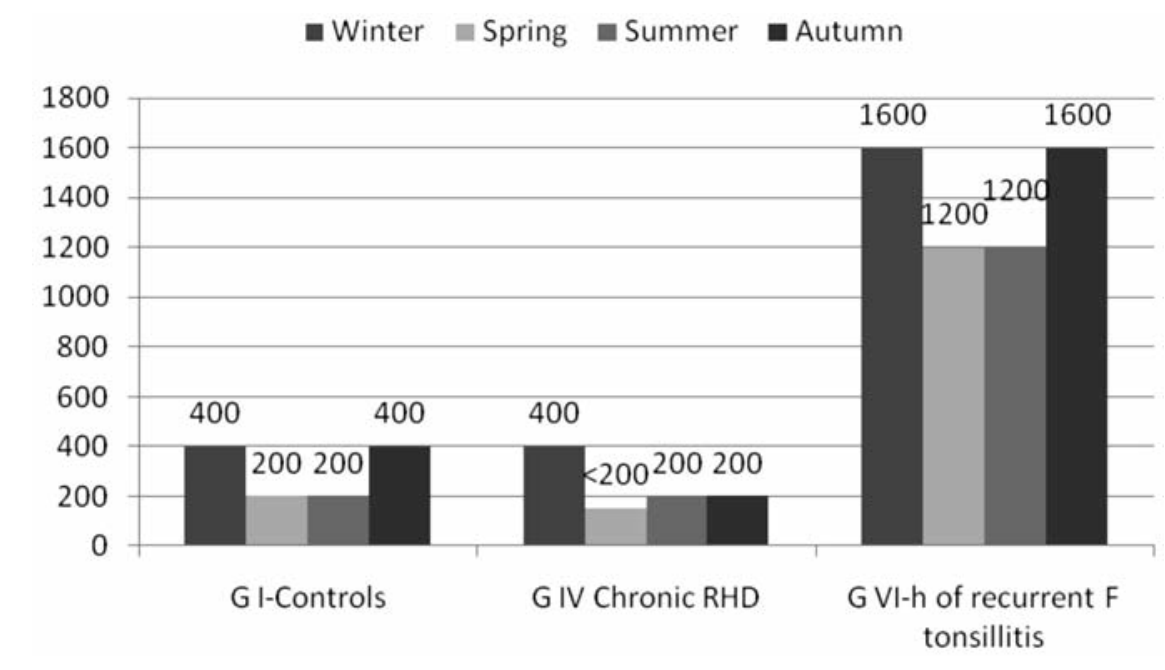

Figure 2. The upper limit of normal of antistreptolysin $O$ titer in IU/mL in groups I, IV and VI in different seasons. ARF, acute rheumatic fever; RHD, rheumatic heart disease; $\mathrm{H}$ of recurrent $\mathrm{F}$ tonsillitis, history of recurrent follicular tonsilli 
Table 1. Antistreptolysin $O$ titer levels in the studied groups.

\begin{tabular}{|c|c|c|c|c|c|c|}
\hline Groups & Controls & $\begin{array}{c}\text { ARF } \\
\text { (1st attack) }\end{array}$ & $\begin{array}{l}\text { Recurrent } \\
\text { RF }\end{array}$ & $\begin{array}{l}\text { Chronic } \\
\text { RHD }\end{array}$ & $\begin{array}{l}\text { Acute follicular } \\
\text { tonsillitis }\end{array}$ & $\begin{array}{l}\text { H of recurrent } \\
\text { f. tonsillitis }\end{array}$ \\
\hline ULN (80th percentile) & 400 & & & 200 & & 1600 \\
\hline $\begin{array}{l}\text { GM } \\
(95 \% \mathrm{CI})\end{array}$ & $\begin{array}{c}245.09 \\
(229.9,261.3)\end{array}$ & $\begin{array}{c}1334.9 \\
(1193.3,1493.4)\end{array}$ & $\begin{array}{c}507.7 \\
(430.1,599.2)\end{array}$ & $\begin{array}{c}215.4 \\
(200.5,231.3)\end{array}$ & $\begin{array}{c}1133.8 \\
(1070.9,1200.22\end{array}$ & $\begin{array}{c}1151.9 \\
(1104.5,1201.3)\end{array}$ \\
\hline
\end{tabular}

ARF, acute rheumatic fever; RHD, rheumatic heart disease; $\mathrm{H}$ of recurrent $\mathrm{F}$ tonsillitis, history of recurrent follicular tonsillitis; ULN, upper limit of normal (80th percentile); GM, geometric mean; CI, confidence interval.

Table 2. Comparison between each two groups as regards the levels of antistreptolysin $\mathrm{O}$ titer.

\begin{tabular}{|c|c|c|c|c|c|}
\hline & $\begin{array}{l}\text { Acute RF } \\
\text { (1st attack) }\end{array}$ & Recurrent RF & Chronic RHD & $\begin{array}{l}\text { Acute f. } \\
\text { tonsillitis }\end{array}$ & $\begin{array}{l}\text { H of recurrent } \\
\text { f. tonsillitis }\end{array}$ \\
\hline 1) Controls & $<0.0001$ & $<0.0001$ & 0.08 & $<0.0001$ & $<0.0001$ \\
\hline 2) Acute RF (1st attack) & & $<0.0001$ & $<0.0001$ & $>0.99$ & $>0.99$ \\
\hline 3) Recurrent RF & & & $<0.0001$ & $<0.0001$ & $<0.0001$ \\
\hline 4) Chronic RHD & & & & $<0.0001$ & $<0.0001$ \\
\hline 5) Acute follicular tonsi & & & & $<0.0001$ & $>0.99$ \\
\hline
\end{tabular}

Table 3. Antistreptolysin $\mathrm{O}$ titer in age based sub-groups .

\begin{tabular}{|c|c|c|c|c|c|c|c|c|}
\hline $\begin{array}{l}\text { Groups } \\
\text { reclassified } \\
\text { according }\end{array}$ & $\begin{array}{l}<200 \\
\mathrm{IU} / \mathrm{mL}\end{array}$ & $\begin{array}{l}200 \\
\mathrm{IU} / \mathrm{mL}\end{array}$ & $\begin{array}{c}400 \\
\text { IU/mL }\end{array}$ & $\begin{array}{l}800 \\
\mathrm{IU} / \mathrm{ml}\end{array}$ & $\begin{array}{l}1200 \\
\mathrm{IU} / \mathrm{mL}\end{array}$ & $\begin{array}{l}1600 \\
\text { IU/mL }\end{array}$ & $\begin{array}{l}1800 \\
\mathrm{IU} / \mathrm{mL}\end{array}$ & $\begin{array}{l}\text { ULN (80th } \\
\text { percentile) }\end{array}$ \\
\hline $\begin{array}{l}\text { Controls } \\
\quad \leq 5 \text { years }=12 \\
6-10 \text { yrs }=114 \\
>10 \mathrm{yrs}=74\end{array}$ & $\begin{array}{c}9(4.5 \%) \\
53(26.5 \%) \\
8(4.0 \%)\end{array}$ & $\begin{array}{c}3(1.5 \%) \\
44(22.0 \%) \\
15(7.5 \%)\end{array}$ & $\begin{array}{c}16(8.0 \%) \\
43(21.5 \%)\end{array}$ & $\begin{array}{l}1(0.5 \%) \\
8(4.0 \%)\end{array}$ & & & & $\begin{array}{l}200 \\
200 \\
400\end{array}$ \\
\hline $\begin{array}{c}\text { ARF (1st attack) } \\
6-10 \text { yrs }=15 \\
>10 \text { yrs }=5\end{array}$ & & & & $\begin{array}{l}1(5.0 \%) \\
1(5.0 \%)\end{array}$ & $\begin{array}{c}8(40.0 \%) \\
1(5.0 \%)\end{array}$ & $\begin{array}{l}3(15.0 \%) \\
3(15.0 \%)\end{array}$ & $3(15.0 \%)$ & \\
\hline $\begin{array}{c}\text { Recurrent ARF } \\
6-10 \mathrm{yrs}=27 \\
>10 \mathrm{yrs}=13\end{array}$ & & $5(12.5 \%)$ & $\begin{array}{l}12(30.0 \%) \\
6(15.0 \%)\end{array}$ & $\begin{array}{l}8(20 \%) \\
6(15 \%)\end{array}$ & $\begin{array}{l}2(5.0 \%) \\
1(2.5 \%)\end{array}$ & & & \\
\hline $\begin{array}{c}\text { Chronic RHD } \\
\leq 5 \mathrm{yrs}=3 \\
6-10 \mathrm{yrs}=61 \\
>10 \mathrm{yrs}=36\end{array}$ & $\begin{array}{c}3(3.0 \%) \\
38(38.0 \%) \\
13(13.0 \%)\end{array}$ & $\begin{array}{l}20(20.0 \%) \\
10(10.0 \%)\end{array}$ & $\begin{array}{c}3(3 \%) \\
10(10 \%)\end{array}$ & $3(3 \%)$ & & & & $\begin{array}{l}<200 \\
200 \\
400\end{array}$ \\
\hline $\begin{array}{c}\text { Acute follicular } \\
\leq 5 \mathrm{yrs}=14 \\
6-10 \mathrm{yrs}=64 \\
>10 \mathrm{yrs}=22\end{array}$ & sillitis & & & $\begin{array}{l}11(11 \%) \\
25(25 \%)\end{array}$ & $\begin{array}{c}3(3 \%) \\
26(26 \%) \\
4(4 \%)\end{array}$ & $\begin{array}{l}13(13 \%) \\
18(18 \%)\end{array}$ & & \\
\hline $\begin{array}{l}\mathrm{H} \text { of Recurrent } \\
\leq 5 \mathrm{yrs}=21 \\
6-10 \mathrm{yrs}=134 \\
>10 \mathrm{yrs}=45\end{array}$ & nsillitis & & $2(1 \%)$ & $\begin{array}{c}9(4.5 \%) \\
44(22.0 \%) \\
10(5.0 \%)\end{array}$ & $\begin{array}{c}5(2.5 \%) \\
46(23.0 \%) \\
16(8.0 \%)\end{array}$ & $\begin{array}{c}7(3.5 \%) \\
42(21.0 \%) \\
19(9.5 \%)\end{array}$ & & $\begin{array}{l}1600 \\
1600 \\
1600\end{array}$ \\
\hline
\end{tabular}

ARF, acute rheumatic fever; RHD, rheumatic heart disease; $\mathrm{H}$ of recurrent $\mathrm{F}$ tonsillitis, history of recurrent follicular tonsillitis; ULN, upper limit of normal; yrs, years ULN (80th percentile).

Table 4. Correlation between the antistreptolysin $\mathrm{O}$ titer and number of attacks of tonsillitis in group 6.

\begin{tabular}{|c|c|c|c|c|c|}
\hline \multicolumn{6}{|c|}{ ASO } \\
\hline N. of attacks & $\mathbf{N}$ & Mean & Std. deviation & F & $\mathbf{P}$ \\
\hline 3 & 52 & 907.69 & 211.29 & & \\
\hline 4 & 58 & 1137.93 & 316.13 & 8.943 & $<0.05$ \\
\hline 5 & 62 & 1406.45 & 237.38 & & $\mathrm{~S}$ \\
\hline 6 & 28 & 1428.57 & 276.03 & & \\
\hline
\end{tabular}


higher reaching $400 \mathrm{IU} / \mathrm{mL}$ owing to the repeated, frequently untreated, streptococcal infection in our community. Thus, for different populations in different geographical locations there may be significant differences in antibody titers. This can be attributed to the climatic or socioeconomic conditions of each locality.12,20

In the current study the ULN (80 th percentile) of ASOT in children with history of repeated tonsillitis (while being free of streptococcal infection) was $1600 \mathrm{IU} / \mathrm{mL}$. This was significantly higher than the value of the control group. We expressed the value of ASOT in terms of upper limit (80 8 th percentile) rather than as mean to show the highest acceptable value in this particular group with previous infection. Although the levels are high, they do not warrant any further investigations or treatment since these children are normal and had no complaint at the time of sampling. Re-infection usually results in sustained or continuously rising titers, and it is known from experimental studies that antibody responses are more impressive on repeated exposure. 12

In the RHD group, ULN and not the mean ASOT was used to identify the levels above which we can diagnose streptococcal infection. The ULN ASOT was lower in RHD (200 IU) than in healthy controls (400 IU). This might be attributed to the effect of penicillin on the immune response to streptococci. ${ }^{21}$ But on the other hand, this does raise concerns that acceptable levels of ASOT in the normal population can be clearly pathological in children under LAP. Similarly, Bosmanskay22 reported an ASOT of $187 \mathrm{IU} / \mathrm{mL}$ in patients with chronic RHD which was significantly lower than the titer in the normal population. The natural course of streptolysin response can be modified by the administration of drugs, especially penicillin, by reducing the overall number of responders, and influencing the magnitude of antibody response. ${ }^{23}$

This study demonstrated a statistically significant difference between the ASOT in patients with ARF 1st attack and patients with recurrent RF. This further supports the hypothesis of an altered immune response to streptococci following LAP prophylaxis. Although recurrence of rheumatic fever is evidence of non compliance to LAP, lower ASOT reflects partial prophylaxis with a decrease in incidence of streptococcal infection. 24,25

There was a significant difference in ASOT according to age in groups without recent streptococcal infection (groups 1,4 and 6) being higher in children over ten years of age owing to the repeated exposure to streptococcal infection. Such a difference was not significant in groups with recent streptococcal infection, indicating an age-dependent basal ASOT, but the pattern of the increase with acute infection was not related to age.
The increase in the levels of ASOT with age was also demonstrated in many other studies. ${ }^{9,10,16,19,26}$ In contrast, in 2005, Danchin et $a l .27$ found that the mean titer of ASO in children over ten years of age $(320 \mathrm{IU} / \mathrm{mL})$ was significantly lower than those between five and ten years, although it was higher than those below five years.

In the current study, the ASOT of each group was significantly higher in winter and autumn. This seasonal variation was also demonstrated in a study conducted in Tehran. ${ }^{28}$ Since streptococcal pharyngitis occurs more during winter, it is not surprising that streptococcal antibody titers are higher in this season. ${ }^{12}$

In the present cohort, there was a significant variation in ASOT according to the type of presentation of rheumatic activity and showed the highest values in patients with acute carditis. This is in agreement with Machado et al. ${ }^{26}$ The high levels seen in acute rheumatic carditis may be due to the time lapse between the streptococcal infection and the occurrence of carditis which allows ASOT to reach its peak level. On the other hand, in patients with chorea by the time the choreic movements appeared the ASO antibodies declined owing to the longer latency period between the streptococcal infection and the clinical manifestation.

In contrast to our study, Roodpeyma and coworkers concluded that variable clinical presentations of rheumatic fever and increasing intensity of cardiac involvement are not related to ASOT. 29

In conclusion, the ULN ASOT in normal Egyptian children is quite high, reaching up to $400 \mathrm{IU} / \mathrm{mL}$. The rise is significant in ARF 1 st attack and acute follicular tonsillitis, but it is less prominent in recurrent attacks of RF. Therefore, an isolated high ASOT is not sufficient to diagnose ARF. Basal levels of ASOT increase with age but age does not affect the peak level during acute streptococcal infection. ASOT shows the highest value in winter. LAP prophylaxis has a prominent effect on the magnitude of the host immune response to streptococci as the ULN (80th percentile) of ASOT was only $200 \mathrm{IU} / \mathrm{mL}$ in patients with chronic RHD, and this should be taken into consideration when diagnosing recurrent rheumatic activity. A twice weekly LAP regimen was associated with the lowest ASOT, suggesting its efficacy in preventing streptococcal throat infection.

\section{References}

1 Madden S, Kelly L. Update on acute rheumatic fever. It still exists in remote communities. Can Fam Physician 2009;55:4758.

2 Carapetis JR, Steer AC, Mulholland EK, Weber M. The global burden of group A streptococcal diseases. Lancet Infect Dis 2005;5:685-94

3 Meador RJ, Russell IJ. Acute Rheumatic Fever. e-medicine Rheumatology Jul 31, 2009. Available from: http://emedicine. medscape.com/article/333103-overview

4 Abdel-Moula AM, Sherif AA, Sallam SA, et al. Prevalence of rheumatic heart disease among school children in Alexandria, Egypt: a prospective epidemiological study. J Egypt Public Health Assoc 1998;73:22254.

5 Kassem AS, Madkour AA, Massoud BZ, Zaher SR. Benzathine Penicillin G for Rheumatic Fever Prophylaxis: 2-Weekly Versus 4-Weekly Regimens. Indian J Pediatr 1992;59:741-8.

6 Kotby AA, Abd Elmoneim MT, Hassan AS. Assessment of rheumatic fever and rheumatic heart disease in the Children's hospital, Ain Shams University. Egypt J Pediatr 1996;3-4:183-205.

7 Carapetis JR, McDonald M, Wilson NJ. Acute rheumatic fever. Lancet 2005; 366 : 155-68.

8 Ferrieri P. Jones Criteria Working Group. Proceedings of the Jones criteria workshop. Circulation 2002;106:2521-31.

9 Kaplan EL, Rothermel CD, Johnson DR. Antistreptolysin 0 and anti-deoxyribonuclease B titers: normal values for children ages 2 to 12 in the United States. Pediatrics 1998;101:86-8

10 Sethi S, Kaushik K, Mohandas K, et al. Anti-Streptolysin 0 Titers in Normal Healthy Children of 5-15 Years. Indian J Pediatr 2003;40:1068-71.

11 Kaplan EL. Rheumatic fever. In: AS Fauci, E Brawnwald, KJ Isselbacher, JD Wilson, JB Martin, Dl Kasper, SL Hauser, DL Longo (eds.) Harrison's Principle of Internal Medicine. 14th ed. McGraw-Hill, New York, 2001, p 1340.

12 Shet A, Kaplan EL. Clinical use and interpretation of group A streptococcal antibody tests: A practical approach for the pediatrician or primary care physician. Pediatr Infect Dis J 2002;21:420-30.

13 Dajani AS, Ayoub E, Bierman FZ. Guidelines for the diagnosis of rheumatic fever: Jones criteria, updated 1992. Circulation 1993;87:302-7.

14 Bisno AL, GerberMA, Gwaltney MJ Jr, et al. Practice guidelines for the diagnosis and management of group A streptococcal pharyngitis. Infectious disease Society of America. Clin Infect Dis 2002;35:113-25.

15 Wannamaker L, Ayoub E. Antibody titers in acute rheumatic fever. Circulation 1960; 21:598-614.

16 Kim S, Lee YN. Asymptomatic infection by Streptococcus pyogenes in school children and diagnostic usefulness of antideoxyribonuclease B. J Korean Med Sci 2005;20: 
938-40.

17 Karmakar MG, Venugopal V, Joshi L, Kamboj R. Evaluation and revaluation of upper limits of normal values of anti-streptolysin 0 and anti deoxyribonuclease B in Mumbai. Indian J Med Res 2004;119:26-8.

18 Mhalu FS, Matre R. Antistreptolysin 0 and antideoxyribonuclease B titres in blood donors and in patients with features of nonsuppurative sequelae of group A streptococcus infection in Tanzania. E Afr Med J 1995;72:33-6.

19 Renneberg J, Söderström M, Prellner K, et al. Age-related variations in anti-streptococcal antibody levels. Eur J Clin Microbiol Infect Dis 1989;8:792-5.

20 Nava A, del Rio L, Aguilar CM, et al. Serum levels of antistreptolysin 0 in teenagers from Mexican urban and rural areas. Rev Alerg Mex 2008;55950;196-200.

21 Gerber MA, Baltimore RS, Eaton CB, et al. Prevention of rheumatic fever and diagnosis and treatment of acute Streptococcal pharyngitis: a scientific statement from the American Heart Association Rheumatic Fever, Endocarditis, and Kawasaki Disease Committee of the Council on Cardiovascular Disease in the Young, the Interdisciplinary Council on Functional Genomics and Translational Biology, and the Interdisciplinary Council on Quality of Care and Outcomes Research: endorsed by the American Academy of Pediatrics. Circulation 2009; 119:1541-51.

22 Bosmansky K. Streptococcus antibodies in a rural population and in patients with inflammatory rheumatic diseases. Z Rheumatol 1985;44:213-7.

23 McCarty M. The hemolytic streptococci. In: RJ Dubos (ed.) Bacterial and mycotic infections of man. 3rd ed. JB Lippincott Co., Philadelphia, 1958, p 248.

24 Robertson KA, Volmink JA, Mayosi BM. Antibiotics for the primary prevention of acute rheumatic fever: a meta-analysis.
BMC Cardiovasc Disord 2005;5:11-20.

25 Cilliers AM. Rheumatic fever and its management. BMJ 2006;333:1153-6.

26 Machado CS, Ortiz K, Martins AB, et al. Antistreptolysin 0 titer profile in acute rheumatic fever diagnosis. J Pediatr 2001;77:105-11.

27 Danchin MH, Carlin JB, Devenish W, et al. New normal ranges of antistreptolysin 0 and antideoxyribonuclease $\mathrm{B}$ titres for Australian children. J Paediatr Child Health 2005;41:583-6.

28 Gharagozloo R, Ghavamian P. The range of antistreptolysin-0 titer among 3129 healthy individuals in winter and summer in Tehran, Iran. Pahlavi Med J 1976;7:32333.

29 Roodpeyma L, Kamali Z, Zare R. Rheumatic fever: the relationship between clinical manifestations and laboratory tests. J Paediatr Child Health 2005;41:97-100. 